\title{
Growing a Gender-Inclusive Biology Curriculum: A Framework and Reflections for Secondary Science Teachers
}

\author{
Sam Long, High School Biology Teacher
}

Sam Long (he/him/his) is a transgender man and a high school biology teacher in Denver, CO

\begin{abstract}
Summary
Arguments that appeal to an oversimplified "biology" are commonly used to exclude transgender people from gender-segregated spaces and from public life. In schools, many transgender youth are mistreated and feel unsafe. Biology teachers have a unique opportunity to change the school climate by teaching in a way that includes and affirms diverse gender identities rather than omitting or alienating them. For teachers, school leaders, and policymakers, I present a framework for a gender-inclusive biology curriculum. I share lessons that I have implemented and my reflections on how this kind of curriculum can positively impact student attitudes, engagement, and learning.
\end{abstract}

Keywords: biology, STEM, curriculum, transgender, gender diversity

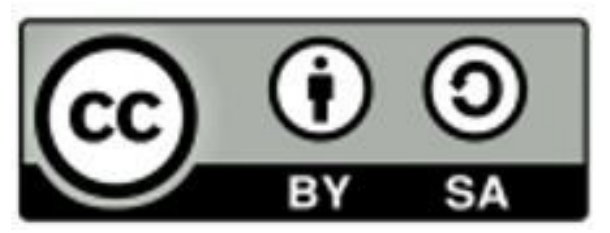

See: creativecommons.org/licenses/by-sa/4.0/ 


\title{
Growing a Gender-Inclusive Biology Curriculum: A Framework and Reflections for Secondary Science Teachers
}

\author{
Sam Long, High School Biology Teacher
}

In October 2018, The New York Times reported that the Trump administration had proposed a new legal definition of sex. "Sex means a person's status as male or female based on immutable biological traits identifiable by or before birth," the memo proposed. If adopted, this definition would erase numerous legal protections for the transgender community. Most notably, transgender individuals would be excluded from Title IX, which prohibits exclusion or discrimination on the basis of sex in federally funded education programs.

The Trump administration's exclusionary appeal to "biology" is all too familiar. On a daily basis, transgender individuals ${ }^{2}$ are told that they do not fit into an overly simplistic, binary definition of a "biological" male or female, and this becomes grounds to exclude them from restrooms, sports facilities, or other public spaces.

As a biology teacher and an out transgender man, I follow these stories closely. I grew up and transitioned in Toronto, Canada, where I was barred from my high school restrooms and overnight trips. For the last four years, I have taught high school in Denver, Colorado. In my classroom, I push students to dig deeper beyond the binary, toward a more complex biology that both affirms and enriches our understanding of gender diversity.

Most science classrooms do not affirm gender diversity. In a 2017 survey, only $2.4 \%$ of students saw positive representations of any LGBTQ-related topic in a science class. Teacher messaging has implications for student safety - the survey reported that $55 \%$ of LGBTQ students who were harassed or assaulted at school did not feel comfortable reporting the incident to school staff. Teachers need guidance on how to reverse this trend, and biology teachers have a unique opportunity to do so through their curriculum. For these teachers, I offer a framework for creating and adapting gender-inclusive biology curriculum.

A gender-inclusive biology curriculum has five essential elements: authenticity, continuity, affirmation, anti-oppression, and student agency.

\footnotetext{
${ }^{2}$ Transgender refers to people whose gender identity does not fully align with their sex assigned at birth.
} 
Figure 1: Framework for a Gender-Inclusive Biology Curriculum

\begin{tabular}{|c|c|}
\hline \multicolumn{2}{|c|}{ Framework for a Gender-Inclusive Biology Curriculum } \\
\hline 1. Authenticity & $\begin{array}{l}\text { - Gender-inclusion is embedded in the curriculum } \\
\text { - Lessons are aligned with the teacher's beliefs } \\
\text { - Content is based on empirical research }\end{array}$ \\
\hline 2. Continuity & $\begin{array}{l}\text { - Gender-inclusion is a recurring part of the curriculum, not a } \\
\text { one-time "very special lesson", an aside, an extension, or a } \\
\text { reaction } \\
\text { - Gender-related themes are consistent from lesson to lesson }\end{array}$ \\
\hline 3. Affirmation & $\begin{array}{l}\text { - Students learn about the naturally-occurring diversity of } \\
\text { gender and sexuality in human and nonhuman species } \\
\text { - Lessons celebrate diversity as a valuable asset in societies } \\
\text { and in scientists }\end{array}$ \\
\hline 4. Anti-oppression & $\begin{array}{l}\text { - Lessons highlight and challenge oppression in current and } \\
\text { historical science practices } \\
\text { - Students ask about what voices are present and absent in the } \\
\text { conversation } \\
\text { - Teachers are aware of their own identity and privileges }\end{array}$ \\
\hline 5. Student agency & $\begin{array}{l}\text { - Students give input and feedback about lessons } \\
\text { - } \text { Teachers ask students what they want to learn more about } \\
\text { - } \quad \text { Students make choices for research projects and case studies }\end{array}$ \\
\hline
\end{tabular}

The first two elements of the framework, authenticity and continuity, ensure that inclusion efforts are internalized by students as a full-fledged part of their education. Affirmation and anti-oppression both help students to find empowerment in the study of gender in biology. Student agency allows students to take ownership in what they are learning, and for students with high interest in these topics to explore them even further.

On the first day of classes, I teach a lesson about Diverse Scientists to develop the mindset that anybody can be a scientist. First, I ask students to draw a scientist using a pencil and paper. I show a handful of drawings on the document camera and ask students to notice trends. Most papers show a white man with wild hair and glasses, holding a beaker that is sometimes exploding. Then we do a gallery walk, viewing twelve posters of real scientists including women, scientists of color, and LGBTQ identities. Students look at portraits and read short biographies of astronaut Mae Jemison, computer scientist Alan Turing, neurobiologist Ben Barres $^{3}$, and others. Then I ask students to reflect on the differences between their drawings and the real scientists. Students notice that the real scientists are far more diverse than the drawings.

\footnotetext{
${ }^{3}$ Barres, a transgender man, shared his pre- and post-transition experiences of discrimination in an autobiography (Barres, 2017).
} 
After this comparison, I tell students explicitly that we are all scientists, even if we have not felt like it in the past. Throughout the year, we study diverse scientists and their often uncredited contributions. These repeated exposures exemplify the continuity and anti-oppression elements of the framework. Although diverse scientists make up a very small portion of instructional time in my class, the representation helps my LGBTQ students to develop a sense of belonging in science. This is needed because LGBTQ scientists are currently underrepresented and often closeted in STEM majors and careers.

My genetics unit is an opportunity to develop understanding about diversity in gender and in families. By the unit's end, students will be able to explain how DNA provides instructions for making essential proteins, and how parental alleles can be used to predict the traits of the offspring. But before we begin, my students must understand the complexities of the language of genetics. On the board, I write the statement, "We get half our DNA from our mom and half from our dad." On the surface, this may sound like a truth pulled straight from a biology textbook. I ask students to consider whether the statement is inclusive-does it apply to every person?

Students are able to express who is not included in this statement, namely children who are adopted, same-sex parents, single parents, and children conceived with a sperm donor. Not every child has exactly two people called 'mom' and 'dad' who share DNA with the child. I explain to the class that although every human is conceived from an egg and a sperm, families are diverse - all families are valid.

Similarly, we consider the statement, "Men produce sperm cells and women produce egg cells." Students know that this is sometimes not true for people who are older, infertile, or transgender. (I add that individuals with intersex traits also may not produce egg or sperm cells). I ask, "Do transgender men count as men? Do infertile women count as women?" and students agree that they count. I highlight the difference between gender identity, which is self-determined, and various measures of physical sex. To conclude, our class agrees on a certain term, usually "biological parent", to refer to someone who passes on their DNA to the child via an egg or sperm cell.

Teaching students this language is important for the authenticity element of the framework. After this discussion, students and teachers are able to approach every genetics lesson with language that is precise and inclusive. Students develop an awareness that the patterns connecting gender, chromosomes, and egg and sperm are just that-generalized patterns, not absolute rules. Students with more curiosity about gender diversity may choose to research intersex traits for the research project within this unit.

My evolution unit is flush with opportunity to address the third element of the framework, affirmation. After learning the basics of natural selection, we explore theories of how homosexual behavior and sex-changing can contribute to the reproductive success of certain animal species. We also learn about diverse reproductive strategies beyond the typical pattern of 
"males compete, females choose." In this unit, students learn that diversity is not to be merely tolerated, but celebrated as an essential and beautiful part of life.

These gender-inclusive lessons elicit some of the highest engagement that I have seen from my students. Discussions are lively and students' questions are sometimes endless. Eyes widen and hands go up from the quiet students who don't normally shine in science class. LGBTQ students lean into the lesson, smile, nod, and sigh with relief when they hear my framing of a topic that is normally taught in a cis heteronormative ${ }^{4}$ way. Each year, more LGBTQ students come out to me, with the trust that their identities will be recognized and celebrated in my biology classroom. Teachers, our students are always listening.

Gender-inclusive biology teaching is a high-leverage way to help all students feel safe, included, and celebrated in school.

${ }^{4}$ Cis heteronormative refers to a worldview that promotes heterosexual and cisgender (non-transgender) identities as normal or preferred. 


\section{References}

Barres, B., \& Hopkins, N. (2018). The autobiography of a transgender scientist. Cambridge, Massachusetts: MIT Press.

Green, Erica L., et al. (2018, October 21). 'Transgender' Could Be Defined Out of Existence Under Trump Administration." The New York Times. Retrieved from www.nytimes.com/2018/10/21/us/politics/transgender-trump-administration-sex-definitio $\underline{\text { n.html }}$

Hughes, B. E. (2018). Coming out in STEM: Factors affecting retention of sexual minority STEM students. Science Advances, 4(3), eaao6373.

Kosciw, J. G., et al. (2018). The 2017 National School Climate Survey: The experiences of lesbian, gay, bisexual, transgender, and queer youth in our nation's schools. New York: GLSEN. 